\title{
Source apportionment of atmospheric ammonia before, during, and after the 2014 APEC summit in Beijing using stable nitrogen isotope signatures
}

\author{
Yunhua Chang ${ }^{1, a}$, Xuejun Liu ${ }^{2}$, Congrui Deng ${ }^{1}$, Anthony J. Dore ${ }^{3}$, and Guoshun Zhuang ${ }^{1}$ \\ ${ }^{1}$ Center for Atmospheric Chemistry Study, Department of Environmental Science and Engineering, Fudan University, \\ Shanghai 200433, China \\ ${ }^{2}$ College of Resources and Environmental Sciences, China Agricultural University, Beijing 100193, China \\ ${ }^{3}$ Centre for Ecology \& Hydrology Edinburgh, Bush Estate, Penicuik, Midlothian EH26 0QB, UK \\ a currently at: Yale-NUIST Center on Atmospheric Environment, Nanjing University of Information Science and Technology, \\ Nanjing 10044, China
}

Correspondence to: Congrui Deng (congruideng@fudan.edu.cn) and Xuejun Liu (liu310@cau.edu.cn)

Received: 19 May 2016 - Published in Atmos. Chem. Phys. Discuss.: 13 June 2016

Revised: 22 August 2016 - Accepted: 6 September 2016 - Published: 20 September 2016

\begin{abstract}
Stable nitrogen isotope composition $\left(\delta^{15} \mathrm{~N}\right)$ offers new opportunities to address the long-standing and ongoing controversy regarding the origins of ambient ammonia $\left(\mathrm{NH}_{3}\right)$, a vital precursor of $\mathrm{PM}_{2.5}$ (particulate matters with aerodynamic diameter equal or less than $2.5 \mu \mathrm{m}$ ) inorganic components, in the urban atmosphere. In this study, the $\delta^{15} \mathrm{~N}$ values of $\mathrm{NH}_{3}$ samples collected from various sources were constrained using a novel and robust chemical method coupled with standard elemental analysis procedures. Independent of the wide variation in mass concentrations (ranging from 33 (vehicle) to over 6000 (human excreta) $\mu \mathrm{g} \mathrm{m}^{-3}$ ), different $\mathrm{NH}_{3}$ sources have generally different $\delta^{15} \mathrm{~N}$ values (ranging from -52.0 to $-9.6 \%$ ). Significantly high $\delta^{15} \mathrm{~N}$ values are seen as a characteristic feature of all vehiclederived $\mathrm{NH}_{3}$ samples $(-14.2 \pm 2.8 \%$ ), which can be distinguished from other sources emitted at environmental temperature $(-29.1 \pm 1.7,-37.8 \pm 3.6$, and $-50.0 \pm 1.8 \%$ or livestock, waste, and fertilizer, respectively).

The isotope $\delta^{15} \mathrm{~N}$ signatures for a range of $\mathrm{NH}_{3}$ emission sources were used to evaluate the contributions of the different sources within measured ambient $\mathrm{NH}_{3}$ in Beijing, using an isotope mixing model (IsoSource). The method was used to quantify the sources of ambient $\mathrm{NH}_{3}$ before, during and after the 2014 Asia-Pacific Economic Cooperation (APEC) summit, when a set of stringent air quality control measures were implemented. Results show that the average $\mathrm{NH}_{3}$ con-
\end{abstract}

centrations (the overall contributions of traffic, waste, livestock, and fertilizer) during the three periods were 9.1 (20.3, 28.3, 23.6, and 27.7\%), 7.3 (8.8, 24.9, 14.3, and 52.0\%), and $12.7(29.4,23.6,31.7$, and $15.4 \%) \mu \mathrm{g} \mathrm{m}^{-3}$, respectively, representing a $20.0 \%$ decrease first and then a $74.5 \%$ increase in overall $\mathrm{NH}_{3}$ mass concentrations. During (after) the summit, the contributions of traffic, waste, livestock, and fertilizer decreased (increased) by 56.7 (234.2), 12.0 (-5.0), 39.4 (120.8), and $-87.7 \%(-70.5 \%)$ when compared with periods before (during) the summit, respectively, signifying that future $\mathrm{NH}_{3}$ control efforts in megacities like Beijing should prioritize traffic sector as well as livestock breeding. The results show that isotope ratio measurements of $\mathrm{NH}_{3}$ to be a valuable tool to quantify the atmospheric sources of $\mathrm{NH}_{3}$ in urban atmospheres.

\section{Introduction}

For more than a century, the Haber-Bosch process has been meeting the Earth's increasing demand for grain and protein through nitrogen fertilizer (Erisman et al., 2008; Sutton et al., 2011). But unintentionally, increasing the application of ammonia $\left(\mathrm{NH}_{3}\right)$ and its derivatives as fertilizer has altered the composition of the atmosphere (Fowler et al., 2009). Fertilizer application merged with livestock production is the 
largest contributor of $\mathrm{NH}_{3}$ emissions (Aneja et al., 2008), which cause cascading effects on human health, ecosystems, and climate (Galloway et al., 2003).

Whilst the overwhelming contribution of agricultural activities to the global and regional $\mathrm{NH}_{3}$ budgets is well accepted, a large number of observations show that the ambient levels of $\mathrm{NH}_{3}$ concentration in cities are comparable with, or even higher than, those in rural areas (e.g., Cao et al., 2009; Meng et al., 2011; Singh and Kulshrestha, 2014; Zbieranowski and Aherne, 2012). Given that the atmospheric behavior of $\mathrm{NH}_{3}$ is characterized by a short lifetime (1-5 days or less) (Warneck, 1999), low transport height, and relatively high dry deposition velocity (Asman and van Jaarsveld, 1992), high rural $\mathrm{NH}_{3}$ emissions do not generally influence urban areas strongly in the gaseous phase unless reacting with acidic gases locally to form particulate $\mathrm{NH}_{4}^{+}$(Flechard et al., 2013). Therefore, other non-agricultural sources must exist in urban areas (Chang, 2014; Sutton et al., 2000). Some authors argue that gasoline-powered vehicles equipped with three-way catalytic converters (TWCs) and diesel-powered vehicles fitted with the selective catalytic reduction system (SCRs) are a major contributor of non-agricultural $\mathrm{NH}_{3}$ (Burgard et al., 2006; T. Liu et al., 2014; Perrino et al., 2002). In the UK, for example, it is estimated that $15 \%$ of the national $\mathrm{NH}_{3}$ emissions originate from non-agricultural activities (Sutton et al., 2000), and 5-6\% of the total $\mathrm{NH}_{3}$ emissions in the USA are derived from vehicles, with almost all the remaining $\mathrm{NH}_{3}$ coming from agricultural processes (Kean et al., 2009). Based on a "bottom-up" methodology, a city-specific non-agricultural $\mathrm{NH}_{3}$ emission inventory for 113 Chinese cities was recently established (Chang, 2014), in which traffic (32.2\%) was identified as the largest $\mathrm{NH}_{3}$ emission source. At the global scale, non-agricultural $\mathrm{NH}_{3}$ emissions are 1 or 2 orders of magnitude smaller than the gross flux of gaseous $\mathrm{NH}_{3}$ between the Earth's surface and the atmosphere, which totals more than $50 \mathrm{Tg} \mathrm{yr}^{-1}$ (Schlesinger and Hartley, 1992). Non-agricultural activities, however, are highly concentrated in urban areas and, therefore, could be supposed to be significant sources of $\mathrm{NH}_{3}$ in cities (Chang et al., 2012). Given the important role of urban $\mathrm{NH}_{3}$ emissions to form $\mathrm{PM}_{2.5}$ (particulate matters with aerodynamic diameter equal or less than $2.5 \mu \mathrm{m}$ ), $\mathrm{NH}_{3}$ emission reduction has been regarded as the key to curb severe haze pollution in Chinese megacities (Ye et al., 2011; Wang et al., 2011, 2013).

Although isotopic techniques have been extensively accepted as a useful tool for source apportionment of gases and PM (e.g., Cao et al., 2011; Felix et al., 2012; J. Liu et al., 2014; Rudolph et al., 1997; Wang et al., 2016; Xiao et al., 2012, 2015; Xiao and Liu, 2002), there have been few studies to date in terms of directly observing or quantifying the contribution of non-agricultural $\mathrm{NH}_{3}$ in the atmosphere (Felix et al., 2014; Liu et al., 2008). Greater scientific attention and regulatory efforts have been given to nitrogen oxides $\left(\mathrm{NO}_{x}=\mathrm{NO}+\mathrm{NO}_{2}\right.$ ) (Felix et al., 2012; Michalski et al., 2014; Walters and Michalski, 2015; Walters et al., 2016,
2015) and sulfur dioxide ( $\left.\mathrm{SO}_{2}\right)$ (Barros et al., 2015; Giesemann et al., 1994; Habicht and Canfield, 1997; Zhelezinskaia et al., 2014). Also, the conventional method for analyzing $\delta^{15} \mathrm{~N}$, using elemental analyzer (EA) combustion with isotope-ratio mass spectrometry (IRMS), normally requires more than $20 \mu \mathrm{g} \mathrm{N}$ for a single solid sample, which poses a considerable challenge for passive sampling devices (Skinner et al., 2006). To overcome this technical restriction, a landmark paper was published by Felix et al. (2013), in which they tried to combine the bromate $\left(\mathrm{BrO}^{-}\right)$oxidation of $\mathrm{NH}_{4}^{+}$ to $\mathrm{NO}_{2}^{-}$with microbial denitrifier methods (bacteria converts $\mathrm{NO}_{2}^{-}$to $\mathrm{N}_{2} \mathrm{O}$ ) to permit the $\mathrm{N}$ isotopic analysis of low concentration $\mathrm{NH}_{4}^{+}$passive samples, featuring the high throughput of sample mass and low toxicity of reagents. However, the microbial denitrifier they used needs careful cultivation and maintenance, which is time-consuming and also may present a challenge for many isotope laboratories. Recently, a novel and robust chemical method for $\delta^{15} \mathrm{~N}-\mathrm{NH}_{4}^{+}$at natural abundance has been developed (D. Liu et al., 2014), which has major advantages over previous approaches: (i) substantially simplified preparation procedures and reduced preparation time particularly compared to the methods in which diffusion or distillation is involved, since all reactions occur in the same vial and separation of $\mathrm{NH}_{4}^{+}$from solution, is not required; and (ii) greater suitability for low volume samples including those with low $\mathrm{N}$ concentration, having a blank size of 0.6 to $2 \mathrm{nmol}$.

The 2014 Asia-Pacific Economic Cooperation (APEC) summit, another major international event after the 2008 Olympic Games, was hosted in Beijing on 3-12 November. To ensure good air quality and traffic flow during the APEC Summit, a set of stringent measures to control atmospheric pollutants, including regulating vehicle travel (restricting traffic based on the odd and even number plate rule), delaying winter heating (for a week), suspending coal-based industries, and closing construction sites, were implemented in Beijing and its neighboring provinces over a month before and during the APEC summit (Chen et al., 2015; J. Li et al., 2015; Tang et al., 2015; Xu et al., 2015b). This provided a unique city-wide experiment to isotopically examine the response of various $\mathrm{NH}_{3}$ sources to such comprehensive and intensive mitigation efforts. In the present study, the isotopic signatures of various $\mathrm{NH}_{3}$ sources in China were determined for the first time. Moreover, the ambient $\mathrm{NH}_{3}$ concentrations and their isotopic compositions were investigated before, during, and after the APEC control period in Beijing. Based on the isotopic signatures of major sources we developed, a stable isotope mixing model was used to quantify the contributions of each $\mathrm{NH}_{3}$ source in order to examine the effect of the control measures. 


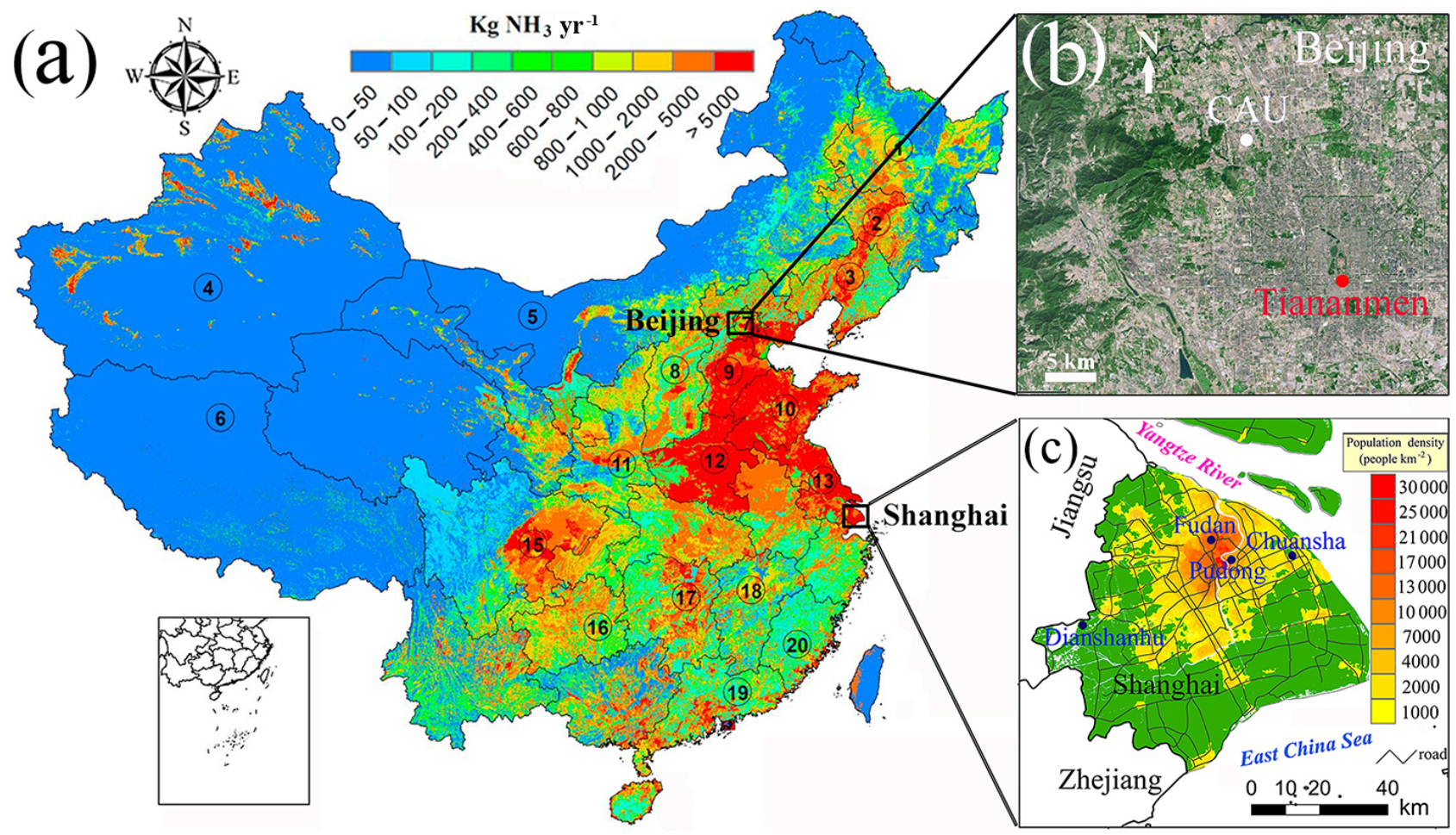

Figure 1. (a) $1 \mathrm{~km} \times 1 \mathrm{~km}$ gridded $\mathrm{NH}_{3}$ emission inventory in China in 2006 (modified from Huang et al., 2012). (b) Location of the sampling site (China Agricultural University or CAU) in this study and its spatial position relative to Tiananmen Square (Beijing urban center). (c) Atmospheric $\mathrm{NH}_{3}$ monitoring network in Shanghai.

\section{Methodology}

\subsection{Ambient $\mathrm{NH}_{3}$ monitoring}

The Adapted Low-Cost Passive High Absorption (ALPHA) samplers (Centre for Ecology and Hydrology, Edinburgh, UK), one of the most widely recognized passive sampling devices (PSDs) (Puchalski et al., 2011; Tang et al., 2001; Xu et al., 2015a), were used to collect ambient $\mathrm{NH}_{3}$ in this study. The ALPHA sampler is a circular polyethylene vial $(26 \mathrm{~mm}$ height, $27 \mathrm{~mm}$ diameter) with one open end. The vial contains a position for a $25 \mathrm{~mm}$ phosphorous acid-impregnated filter and a PTFE (polytetrafluoroethylene) membrane for gaseous $\mathrm{NH}_{3}$ diffusion. In the current study, triplicate $\mathrm{AL}$ PHA filters were used to collect $\mathrm{NH}_{3}$ for IRMS at weekends (from Saturday to Monday) or weekdays (from Monday to Saturday) on the roof of a four-story building (12 ma.g.l.) on the campus of the China Agricultural University (CAU), Beijing $\left(116.289^{\circ} \mathrm{E}, 40.032^{\circ} \mathrm{N}\right)$, before $(18-20,20-25,25-$ 27 October, 27 October-1 November, 1-3 November), during (3-8, 8-10, 10-15 November), and after (15-17, 17-22, 22-24, 24-29 November) the APEC summit (normally at 08:00 local time). The site of the CAU campus represents a general urban background with relatively low-rise buildings in the surrounding area, ca. $16.3 \mathrm{~km}$ northwest of Tiananmen Square (Fig. 1). In this study, the three filters of one sam- pling event were combined for a single analysis. Hourly mass concentrations of gases $\left(\mathrm{CO}, \mathrm{SO}_{2}, \mathrm{NO}_{x}\right.$, and $\left.\mathrm{O}_{3}\right)$ and $\mathrm{PM}_{2.5}$ in Beijing are averaged from the data obtained from the 14 state-controlled environmental monitoring stations across the city (http://datacenter.mep.gov.cn/).

\section{$2.2 \quad \mathrm{NH}_{3}$ source sampling}

The Ogawa passive sampling device (Ogawa \& Co., FL, USA) is another popular PSD that has been successfully applied in the USA (Butler et al., 2015; Puchalski et al., 2011) and China (Chang et al., 2015; Meng et al., 2011) to determine the time-integrated $\mathrm{NH}_{3}$ concentrations. The Ogawa PSD is a double-sided passive diffusion sampler equipped with a diffusive end cap, followed by a stainless-steel screen, and a $14 \mathrm{~mm}$ quartz filter impregnated with phosphoric acid by the manufacturer. In this study, the Ogawa PSDs were used to collect $\mathrm{NH}_{3}$ emitted from sources for isotopic analysis.

Six $\mathrm{NH}_{3}$ emission sources were involved in this study, i.e., livestock (two pig sties), fertilizer volatilization (laboratory simulation of $\mathrm{NH}_{3}$ volatilization from urea-fertilized soil), human excreta (septic tanks of a residential building and a teaching building), waste water (sewage water treatment plant), solid waste (municipal waste transfer stations in a residential community and an educational area), and vehi- 
Table 1. $\delta^{15} \mathrm{~N}-\mathrm{NH}_{3}$ values of ammonia sources, source location, and summer-winter comparison (mean $\left.\pm \mathrm{SD}\right)$.

\begin{tabular}{llllrrr}
\hline Category & Sub-category & Location & Season & $\mathrm{NH}_{3}$ conc. $\left(\mu \mathrm{g} \mathrm{m}^{-3}\right)$ & $\delta^{15} \mathrm{~N}_{-} \mathrm{NH}_{3}(\% \circ)$ & $\mathrm{N}$ \\
\hline \multirow{2}{*}{ Livestock } & \multirow{2}{*}{ pig } & Shanghai pig & summer & $1329.6 \pm 175.8$ & $-30.3 \pm 1.3$ & 3 \\
& & farm & winter & $586.6 \pm 113.2$ & $-28.2 \pm 1.5$ & 4 \\
\hline \multirow{2}{*}{ Traffic } & \multirow{2}{*}{ on-road vehicle } & Handan tunnel & summer & $85.2 \pm 6.2$ & $-12.0 \pm 1.8$ & 4 \\
& & & winter & $46.7 \pm 14.3$ & $-16.5 \pm 1.1$ & 4 \\
\hline \multirow{2}{*}{ Waste } & \multirow{2}{*}{ solid waste } & municipal waste & summer & $443.4 \pm 92.6$ & $-31.1 \pm 1.0$ & 4 \\
& \multirow{2}{*}{ wastewater } & transfer stations & winter & $315.0 \pm 48.5$ & $-36.6 \pm 0.9$ & 4 \\
& \multirow{2}{*}{ wastewater } & summer & $246.3 \pm 9.3$ & $-41.3 \pm 0.7$ & 4 \\
& treatment plant & winter & $143.8 \pm 12.3$ & $-40.7 \pm 1.1$ & 4 \\
& & septic tanks & summer & $4578.4 \pm 1400.3$ & $-38.4 \pm 0.9$ & 4 \\
& & winter & $4440.1 \pm 1288.6$ & $-38.6 \pm 1.0$ & 4 \\
\hline \multirow{2}{*}{ Fertilizer } & \multirow{2}{*}{ urea } & Fudan lab & / & $396.3 \pm 199.9$ & $-50.0 \pm 1.8$ & 5 \\
\hline
\end{tabular}

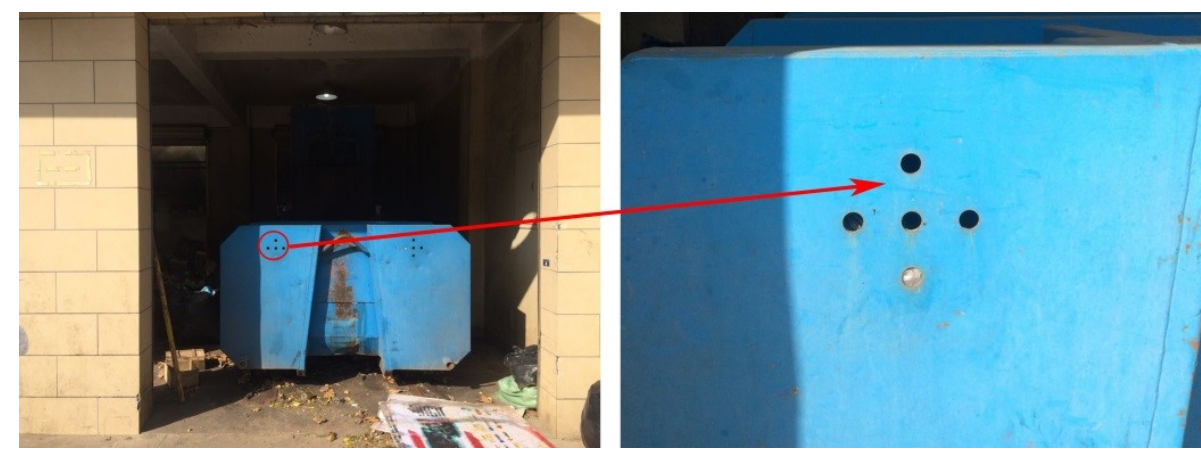

Figure 2. Field photos of a solid waste container in the solid waste transfer station we used for source sampling at Fudan University. Before sampling, an Ogawa passive sampler for $\mathrm{NH}_{3}$ is attached on a plastic strip (1.5 $\mathrm{m}$ in length). The sampler is fitted into the container through the holes (shown on the right panel).

cles (a heavily used urban tunnel) (Tables 1 and S1 in the Supplement). $\mathrm{NH}_{3}$ emitted from fertilizer volatilization was collected in the laboratory of Fudan University. To minimize the mixture of ambient atmospheric $\mathrm{NH}_{3} / \mathrm{NH}_{4}^{+}$(see Figs. 2 and $\mathrm{S} 1$ for two examples) and to examine the potential influence of the macro-environment, non-laboratory samples were collected within a confined space in short periods (e.g., several hours) during both the warm (summer) and cold seasons (winter) between June 2014 and January 2015. Descriptions of the sampling processes are detailed in Table S1.

The ambient average $\mathrm{NH}_{3}$ concentration was less than $6 \mu \mathrm{g} \mathrm{m}^{-3}$ (Chang et al., 2016), which was between 1 and 3 orders of magnitude smaller than all emission sources we investigated (Table 1). Therefore, the interference of ambient air to all source samples is not a major concern in our study. HONO has been measured in significant concentrations in the $\mathrm{UK}$ and interfered with measurements of $\mathrm{HNO}_{3}$ by DELTA active samplers, causing us now to coat the instrument with $\mathrm{NaCl}$ to avoid this interference with $\mathrm{HNO}_{3}$ measurements. The Ogawa filters used for trapping $\mathrm{NH}_{3}$ were impregnated with citric acid. Using a discrete auto analyzer
(Smartchem 200, AMS, Italy; the detection limit for $\mathrm{NO}_{2}^{-}$$\mathrm{N}$ is $0.002 \mathrm{mg} \mathrm{L}^{-1}$ ), we recently analyzed nearly 100 passive filter samples collected from our passive ammonia network in Shanghai (Fig. 1). No detectable nitrite was found for almost all these samples (including samples collected from a busy road tunnel; Chang et al., 2016), which provides compelling evidence that passive collection of ammonia does not introduce interference of nitrite in this study.

In our pilot study, the sampling period of each source was optimized to avoid insufficiency of $\mathrm{NH}_{3}$ absorption, but more importantly, to minimize potential effects of $\mathrm{N}$ isotope fractionation. Taking the source of human excreta for example, the concentrations of $\mathrm{NH}_{3}$ in the exhausts of 15 ceiling ducts from collecting septic tanks in 13 buildings with 6 func-

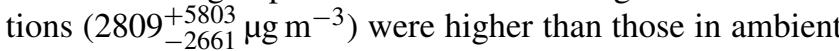
air by 3 orders of magnitude (Chang et al., 2015). Therefore, the insufficiency of $\mathrm{NH}_{3}$ absorption is of no significant concern. However, the $\delta^{15} \mathrm{~N}-\mathrm{NH}_{3}$ values of daily samples varied widely $( \pm 10 \%$ ), suggesting that the isotope fractionation may occur during the process of sampling/storage. After many tests by trial and error, we found that a sam- 
pling period of $2 \mathrm{~h}$ could provide sufficient $\mathrm{N}-\mathrm{NH}_{3}$ as well as avoid potential fractionation. Another example is the onroad traffic source. The $\delta^{15} \mathrm{~N}-\mathrm{NH}_{3}$ values of weekly $(-11.9$; $-11.2 \%$ ) , semi-monthly $(-11.7 ;-12.5 \%$ ), and monthly samples $(-12.0 \pm 1.8 \%$; $n=4)$ in the exit of Handan tunnel were almost identical, suggesting that passive $\mathrm{NH}_{3}$ collection is an effective approach for isotopic analysis procedures.

\subsection{Stable isotope analysis}

A newly developed chemical method for $\delta^{15} \mathrm{~N}-\mathrm{NH}_{4}^{+}$of low $\mathrm{NH}_{4}^{+}$samples was used in the current study. The detailed analytical procedures are given elsewhere (D. Liu et al., 2014). Briefly, this method is based on the isotopic analysis of $\mathrm{N}_{2} \mathrm{O}$, which is much less abundant in the atmosphere than $\mathrm{N}_{2}$ and thus causes minimal atmospheric contamination. Filter samples were firstly soaked with ultra-pure water $(18.2 \mathrm{M} \Omega \mathrm{cm})$. Concentrations of $\mathrm{NH}_{4}^{+}$were then analyzed using an ion chromatographic system (883 Basic IC plus, Metrohm Co., Switzerland) equipped with a Metrosept C4/4.0 cation column. The eluent was $1.0 \mathrm{mM} \mathrm{HNO}_{3}+0.5 \mathrm{mM}$ PDA. The detection limit for $\mathrm{NH}_{4}^{+}$was $0.0028 \mathrm{mg} \mathrm{L}^{-1}$. After the measurement of the $\mathrm{NH}_{4}^{+}$concentration, $\mathrm{NH}_{4}^{+}$in every sample was initially oxidized to $\mathrm{NO}_{2}^{-}$by hypobromite $\left(\mathrm{BrO}^{-}\right)$ in a vial. $\mathrm{NO}_{2}^{-}$was then quantitatively converted into $\mathrm{N}_{2} \mathrm{O}$ by hydroxylamine $\left(\mathrm{NH}_{2} \mathrm{OH}\right)$ under strongly acid conditions. The produced $\mathrm{N}_{2} \mathrm{O}$ was analyzed by a purge and cryogenic trap system (Gilson GX-271, IsoPrime Ltd., Cheadle Hulme, UK) coupled to an IRMS (PT-IRMS) (IsoPrime 100, IsoPrime Ltd., Cheadle Hulme, UK) at the Stable Isotope Ecology Laboratory of Institute of Applied Ecology, Chinese Academy of Sciences.

Isotope ratio values are reported in parts per thousand relative to atmospheric $\mathrm{N}_{2}$ as follows:

$\delta^{15} \mathrm{~N}(\% \circ)=\frac{\left({ }^{15} \mathrm{~N} /{ }^{14} \mathrm{~N}\right)_{\text {sample }}-\left({ }^{15} \mathrm{~N} /{ }^{14} \mathrm{~N}\right)_{\mathrm{N}_{2}}}{\left({ }^{15} \mathrm{~N} /{ }^{14} \mathrm{~N}\right)_{\mathrm{N}_{2}}} \times 1000$.

Three international $\mathrm{NH}_{4}^{+}$standards (IAEA N1, USGS 25, and USGS26 with $\delta^{15} \mathrm{~N}$ values of $+0.4,-30.4$, and $+53.7 \%$ o, respectively) were used to correct for the reagent blank and drift during isotope analysis of the produced $\mathrm{N}_{2} \mathrm{O}$. The standard deviation of $\delta^{15} \mathrm{~N}$ measurements is less than $0.3 \%$. Moreover, to enhance our confidence in the results determined by the PT-IRMS method, the $\delta^{15} \mathrm{~N}$ values of fertilizer-, vehicle-, human excreta-, and solid waste-derived $\mathrm{NH}_{3}$ were also examined by the EA-IRMS method at the Shanghai Institutes of Life Sciences, Chinese Academy of Sciences (Supplement Sect. S1).

\subsection{Isotope mixing model}

Stable isotope mixing models offer a statistical framework to estimate the relative contributions of multiple sources to a mixture, such as food-web structure, plant water use, air pollution, and many other environments (Cole et al., 2011; Dai et al., 2015; Jautzy et al., 2015; Wang et al., 2016). A common problem, however, is having too many possible sources relative to isotopes to allow unique linear mixing solutions based on mass-balance equations. To this end, Phillips and Gregg (2003) developed the model IsoSource, which solves iteratively for feasible mixing solutions, and has been well tested in numerous studies (e.g., Cole et al., 2011; Dai et al., 2015; Jautzy et al., 2015; Wang et al., 2016). The model does not generate exact values for proportional contributions of each source, but instead provides a range of possible contributions or feasible solutions. The IsoSource addresses every possible combination of source proportions (summing to $100 \%$ ) incrementally (e.g., $1 \%$ ), then calculates the predicted isotope value for each combination using linear mass-balance equations. These predicted values are then examined to determine which ones fall within some tolerance range (typically $0.1 \%$ ) of the observed consumer isotope value, and all of these feasible solutions are recorded. The IsoSource model is available at https://www.epa.gov/eco-research/ stable-isotope-mixing-models-estimating-source-proportions.

Considering the large number of possible sources for ambient $\mathrm{NH}_{3}$, we use multiple lines of evidence (prior information) to constrain the emission sources in the mixing model analysis: (1) there was no crop harvest activity in the North China Plain (NCP) during the APEC summit in Beijing. Besides, harvesting forests for fuelwood and timber has nearly disappeared in Beijing. Therefore, the contribution of biomass burning is considered minimal; (2) Beijing is $150 \mathrm{~km}$ inland from the Bohai Sea (the nearest sea) via Tianjin Municipality in the southeast. Therefore, the marine source in Beijing can be neglected; and (3) previous work indicated that miscellaneous $\mathrm{NH}_{3}$ sources like pets and household products are minor $\mathrm{NH}_{3}$ emissions in Beijing urban areas (Chang, 2014), which thus can be largely neglected.

In conclusion, ambient $\mathrm{NH}_{3}$ in Beijing during our study period has been shown to be due to four main sources: livestock production, $\mathrm{N}$-fertilizer application, on-road traffic emissions, and waste-derived emissions. The $\delta^{15} \mathrm{~N}$ average values for these four $\mathrm{NH}_{3}$ emission sources will be built and served as the baseline input to the IsoSource. For the traffic source, given that the relatively larger difference in terms of their $\delta^{15} \mathrm{~N}$ values in different seasons (see Table 1), the wintertime average value of $\delta^{15} \mathrm{~N}$ was used in this study because the APEC summit was held during winter. In brief, the $\mathrm{N}$ isotopic signatures for the sources of waste, livestock, traffic, and fertilizer are set as $-37.8,-29.1,-16.5$, and $-50.0 \%$, respectively (Tables 1 and $\mathrm{S} 1$ ). The source increment and mass-balance tolerance parameter values of $1 \%$ and $0.1 \%$, respectively, were applied. Model output files include all the feasible source combinations, with histograms and descriptive statistics on the distributions for each source. Results are expressed as box-and-whisker plots for these distributions. 


\section{Results and discussion}

\subsection{Isotopic signatures of $\mathrm{NH}_{3}$ emission sources}

Using $\mathrm{N}$ isotope as a tool to discriminate the contribution of various sources to ambient $\mathrm{NH}_{3}$ concentration requires (i) well-established $\mathrm{N}$ isotopic compositions of $\mathrm{NH}_{3}$ emission sources and (ii) well-constrained $\mathrm{N}$ isotope fractionation to allow separating different sources. In total of $44 \mathrm{NH}_{3}$ source samples in this study, $\delta^{15} \mathrm{~N}$ values and $\mathrm{NH}_{3}$ concentrations of these samples ranged from -52.0 to $-9.6 \%$, and 33 to $6211 \mu \mathrm{g} \mathrm{m}^{-3}$, respectively (all data are presented in Table $\mathrm{S} 1$ ). These $\mathrm{NH}_{3}$ sources can be classified into four categories, i.e., fertilizer, livestock, traffic, and waste. For most sources, there was no significant difference in terms of their $\delta^{15} \mathrm{~N}$ values in different seasons (Table 1), indicating the effectiveness of our sampling strategy. The work of Felix et al. (2013) addressed some of the same issues and we found and reported similar results for the range of $\delta^{15} \mathrm{~N}-\mathrm{NH}_{3}$ values $\left(-56.1\right.$ to $-2.2 \%$ ) from major $\mathrm{NH}_{3}$ emission sources (including livestock, marine, vehicle, and fertilizer sources) as those presented here. These two independent studies determining the $\delta^{15} \mathrm{~N}$ values of major $\mathrm{NH}_{3}$ sources arrive at the same conclusion: $\mathrm{NH}_{3}$ emitted from volatilized sources has relatively low $\delta^{15} \mathrm{~N}$ values, allowing them to be distinctly differentiated from $\mathrm{NH}_{3}$ emitted from traffic sources that are characterized by relatively high $\delta^{15} \mathrm{~N}$ values.

Road tunnels are excellent locations to provide emissions from a large number of vehicles mixed with SCRs and TWCs under "real-world conditions" (T. Liu et al., 2014). Here we assume that the $\delta^{15} \mathrm{~N}-\mathrm{NH}_{3}$ values collected from a heavily used tunnel like the Handan tunnel (around 120000 vehicles passing per day; an average of $65.9 \mu \mathrm{g} \mathrm{m}^{-3} \mathrm{NH}_{3}$ or 12.4 times the levels of open environment (Chang et al., 2016) can be accepted as the isotopic signatures of vehicles in China. Nevertheless, we note the $\delta^{15} \mathrm{~N}-\mathrm{NH}_{3}$ values of vehicle exhausts that we collected from the Handan tunnel $(-17.8$ to $-9.6 \%$; $n=8)$ are lower than the $\delta^{15} \mathrm{~N}-\mathrm{NH}_{3}$ values determined by Felix et al. (2013) in the Squirrel Hill Tunnel, Pittsburgh $(-4.6$ and $-2.2 \% ; n=2)$. This Sino-US difference may be partially attributed to a higher usage of TWCs in the traffic in the USA.

The $\delta^{15} \mathrm{~N}$ values of $\mathrm{NH}_{3}$ from livestock $(-31.7$ to $-27.1 \%$ ) and fertilizer ( -52.0 to $-47.6 \%$ ) that we measured are slightly lower than the range of $\delta^{15} \mathrm{~N}-\mathrm{NH}_{3}$ values collected monthly from two dairy barns ( -28.5 to $-22.8 \%$ o) and a cornfield treated with urea-ammonia-nitrate fertilizer $(-48.0$ to $-36.3 \%$ ) by Felix et al. (2013). These ranges of $\delta^{15} \mathrm{~N}$ values are a function of the initial $\delta^{15} \mathrm{~N}$ values of animal waste and fertilizer and variations in the bacteria populations, as well as other factors (temperature, wind, $\mathrm{pH}$, etc.) that influence kinetic fractionation rates associated with $\mathrm{NH}_{3}$ volatilization. Long-term (30 days) monitoring of $\delta^{15} \mathrm{~N}$ and $\mathrm{NH}_{3}$ emissions of manure measured by Lee et al. (2011) indicated that the dynamics of $\mathrm{N}$ isotope fractionation may be complicating the usefulness of the isotope approach as a tool for estimating $\mathrm{NH}_{3}$ emissions in field conditions. In this sense, the shorter sampling period in our work should reflect the essence of $\delta^{15} \mathrm{~N}$ values of livestock- and fertilizer-derived $\mathrm{NH}_{3}$.

As a normal metabolic process, the release of $\mathrm{NH}_{3}$ from human excreta has been well documented. However, most emission inventories involving human excreta have focused on pit latrines in rural areas of developing and middle income countries. In urban China, human excreta are typically stored in a three-grille septic tank under the building before disposal. After a series of anaerobic decomposition processes, a substantial amount of $\mathrm{NH}_{3}$ will be generated and emitted through a ceiling duct. In the present study, the concentrations of $\mathrm{NH}_{3}$ in the ceiling ducts $\left(4509.3 \pm 1248.0 \mu \mathrm{g} \mathrm{m}^{-3}\right.$; $n=8$ ) outweigh those in the open air by 3 orders of magnitude, and the $\delta^{15} \mathrm{~N}-\mathrm{NH}_{3}$ values are seasonally consistent $(-38.4 \pm 0.9 \%$ in summer and $-38.6 \pm 1.0 \%$ in winter; Table 1), suggesting that human excreta may be an important and consistent source of $\mathrm{NH}_{3}$ in urban areas. These data suggest that emissions of $\mathrm{NH}_{3}$ from human excreta for an urban population of $\sim 21$ million people in Shanghai contribute $1386 \mathrm{Mg} \mathrm{NH} 3$ annually to the atmosphere within the city, which corresponds to $11.4 \%$ of the total $\mathrm{NH}_{3}$ emissions in the Shanghai urban areas (Chang et al., 2015). The $\delta^{15} \mathrm{~N}$ values of wastewater-originated $\mathrm{NH}_{3}(-41.0 \pm 0.9 \% ; n=8)$ are close to that of human excreta and also show no seasonal variation. Sampling in a stable and closed physical environment may be responsible for such a small range of isotopic variation. However, although also sampled in a closed environment, the $\delta^{15} \mathrm{~N}$ values of municipal solid waste demonstrate a much greater variation ( -37.6 to $-29.9 \%$ ), which may be due to the variable composition of solid waste.

\subsection{Source apportionment of ambient $\mathrm{NH}_{3}$ in Beijing}

Hourly observations of major air pollutants (including $\mathrm{PM}_{2.5}$, $\mathrm{NO}_{x}, \mathrm{CO}, \mathrm{SO}_{2}$, and $\mathrm{O}_{3}$ ) in Beijing are show in Fig. $\mathrm{S} 2$. The meteorological differences (e.g., temperature and wind speed) for the three periods pre-, during and post-APEC are not significant, suggesting that emission reduction strategies implemented during the APEC summit were successful (Fig. S2). It should be noted that several control measures, i.e., closing factories within $200 \mathrm{~km}$ of the city center and stopping the entrance of out-of-city vehicles, had been undertaken in Beijing and its neighboring regions before the summit. Therefore, the before-during comparison of some pollutants like $\mathrm{SO}_{2}$ are not in stark contrast in terms of their mass concentration (Fig. S2). The evolution of ambient $\mathrm{NH}_{3}$ mass concentrations measured at CAU shows a similar pattern with $\mathrm{CO}$ and $\mathrm{NO}_{x}$ (Fig. S3). Before the opening of the summit (from 18 October to 3 November), $\mathrm{NH}_{3}$ concentrations averaged $9.9 \mu \mathrm{g} \mathrm{m}^{-3}$ and ranged from 6.9 to $11.0 \mu \mathrm{g} \mathrm{m}^{-3}$. During the summit session (from 3 to 15 November, the ending date of the summit is 13 November), this was reduced to 
$7.3 \mu \mathrm{g} \mathrm{m}^{-3}$ with a range of $5.8-8.6 \mu \mathrm{g} \mathrm{m}^{-3}$. After the APEC summit (from 15 to 29 November), the $\mathrm{NH}_{3}$ concentration levels rebounded to an average of $12.7 \mu \mathrm{g} \mathrm{m}^{-3}$ (ranging from 10.7 to $17.7 \mu \mathrm{g} \mathrm{m}^{-3}$ ). In other words, the $\mathrm{NH}_{3}$ concentrations were reduced by $20.0 \%$ during the APEC summit compared with the period before it. Compared with the period after control, the concentrations were $74.5 \%$ lower than that during the summit (Table 2).

On the basis of the $\delta^{15} \mathrm{~N}$ values of $\mathrm{NH}_{3}$ emission sources and ambient $\delta^{15} \mathrm{~N}-\mathrm{NH}_{3}$ samples (Table 2), the ranges (within 5 and 95 percentiles) of relative contribution fractions of each $\mathrm{NH}_{3}$ source to the ambient atmosphere were modeled by the IsoSource and depicted in Fig. 3a-d. Of these, sources of traffic and fertilizer are better constrained than livestock and waste. This is because the $\delta^{15} \mathrm{~N}-\mathrm{NH}_{3}$ values of the ambient atmosphere are closer to the latter two. For example, after the APEC summit in our study period, the $\delta^{15} \mathrm{~N}-\mathrm{NH}_{3}$ values of the ambient atmosphere averaged $-30.7 \%$, which is very close to the isotopic signature of livestock $(-29.1 \%)$, thus leading to weaker constraint with 5 and 95 percentiles ranges from near 0 to 0.7 (Fig. 3).

For each sample, information regarding the $\delta^{15} \mathrm{~N}$ value, the $\mathrm{NH}_{3}$ concentration and its source contributions is listed in Table 2. Figure 4 illustrates the overall source contribution proportions before, during, and after the summit, in which traffic, waste, livestock, and fertilizer comprised 20.4, 25.9, 24.0 , and $29.7 \%$ of the whole period (Table 2), respectively. Specifically, the contribution of traffic initially decreased by $56.7 \%$ and then doubled, and this represents the largest change among the four sources (Table 2). Considering the absolute contributions of different sources to ambient $\mathrm{NH}_{3}$, these results show that traffic is the most sensitive source to the emission control measures. This result was expected since over half the vehicles in Beijing were banned from entering the city during the APEC summit (note that before the summit, out-of-city vehicles had already been banned from entering Beijing). Based on the vehicle $\mathrm{NH}_{3}$ emission factor obtained from real-world tunnel tests, T. Liu et al. (2014) and Chang et al. (2016) recently reported that vehicles contribute 8.1 and $12.0 \%$ to total $\mathrm{NH}_{3}$ emissions in the Pearl River Delta region and Shanghai urban areas, respectively. With a total of 5.5 million vehicles in 2014, the traffic fleet in Beijing was much more than other cities. Thus, vehicle sources might contribute more than $20 \%$ of the total $\mathrm{NH}_{3}$ to the air within Beijing.

The waste-originated percentages in Figs. 3 and 4 remain fairly constant over the sampling period, appearing to be a stable and important $\mathrm{NH}_{3}$ contributor in Beijing. Compared with wastewater and solid water, $\mathrm{NH}_{3}$ emissions from human excreta through in situ sceptic tank system are far from quantified. Based on an extensive measurement campaign, we estimated that the population of $\sim 21$ million people living in the urban areas of Shanghai annually emitted approximately $1386 \mathrm{Mg} \mathrm{NH}_{3}$, which corresponds to over $11.4 \%$ of the total $\mathrm{NH}_{3}$ emissions in the urban areas (Chang et al., 2015). Non-

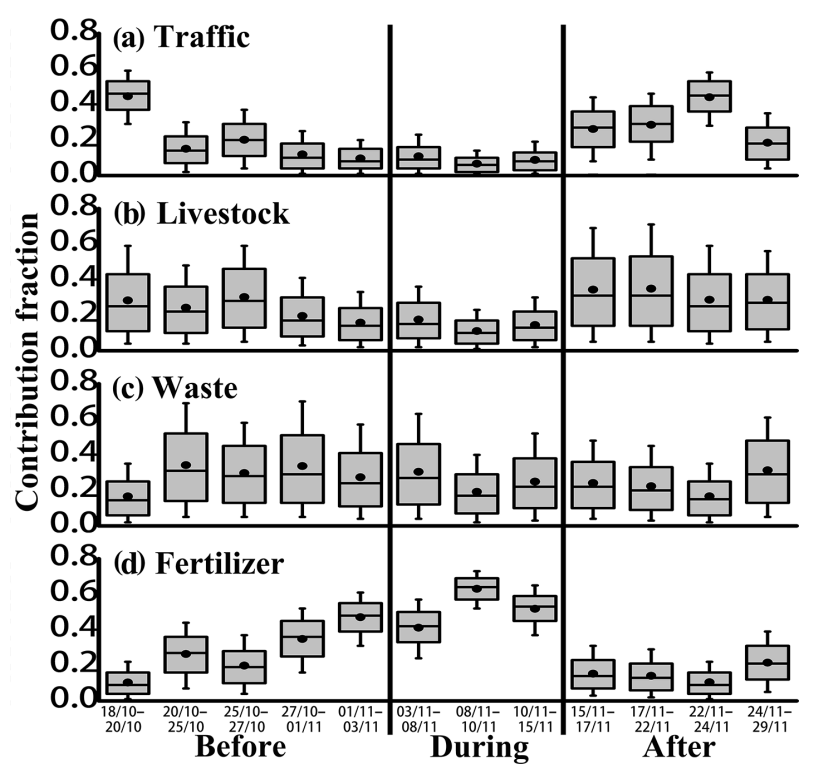

Figure 3. Time series of the box-whisker plots of the contribution fraction of ambient $\mathrm{NH}_{3}$ from different sources estimated from the IsoSource model. The box boundaries represent the 25th and 75th percentile, the horizontal line is the median, and the whiskers mark the 10th and 90th percentiles. The dots denote the mean values of the distribution.

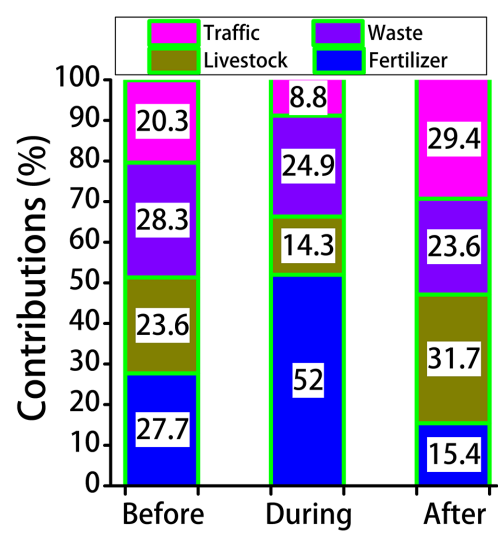

Figure 4. The overall contribution proportion (\%) of the four sources to ambient $\mathrm{NH}_{3}$ identified by the IsoSource before, during, and after the APEC summit in Beijing.

agricultural sources - merged with waste and traffic $\mathrm{NH}_{3}$ emissions - collectively account for nearly $50 \%$ of ambient $\mathrm{NH}_{3}$ before and after the APEC summit, which cannot be explained by previous work of emission inventories (e.g., Fu et al., 2013; Huang et al., 2011, 2012; Kang et al., 2016; M. Li et al., 2015; Zhang et al., 2009, 2010). Our results do not contradict a commonly held belief that agriculture is responsible for the vast majority (normally $>90 \%$ ) of total ammonia emissions at a regional scale. However, the results show that within urban areas, non-agricultural sources are very important. A consequence of the new results is that measures to im- 


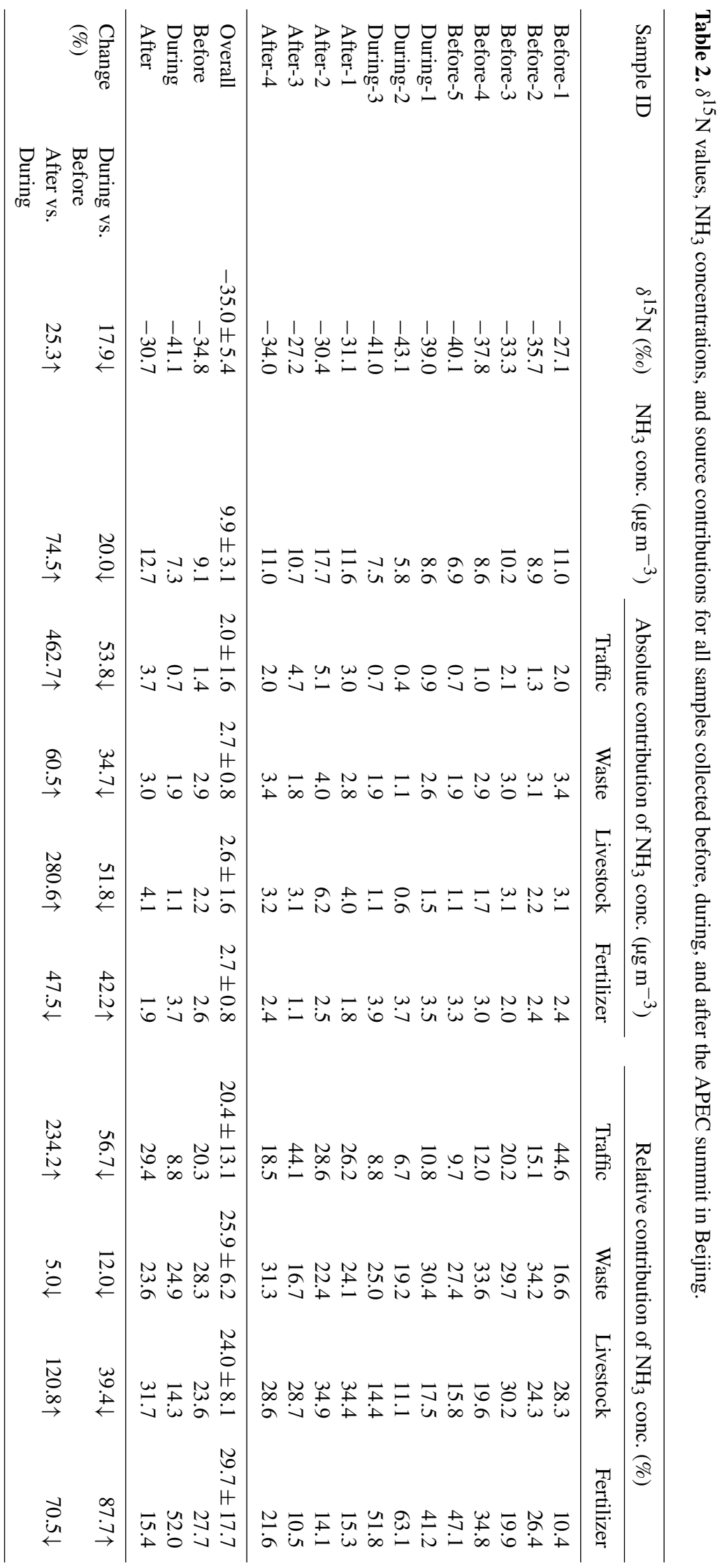


prove air quality in urban areas of China need to include measures to reduce both agricultural and non-agricultural sources of $\mathrm{NH}_{3}$.

The NCP is one of the most intensive agricultural regions in China, enjoying a good reputation of "China's granary" (Ju et al., 2009). Situated on the northern edge of the NCP with mountains to the north and west, Beijing is a receptor of agricultural $\mathrm{NH}_{3}$ from rural areas. During our study period, crops in the NCP had been harvested and thus fertilizer application would have been very limited. However, our results show that fertilizer is the largest contributor, accounting for $29.7 \%$ throughout the sampling periods (Table 2). One explanation might be the prevalence of intensive urban agricultural production with high nitrogen fertilizer input in the suburban areas. Beijing's increase in land area from $4822 \mathrm{~km}^{2}$ in 1956 to $16808 \mathrm{~km}^{2}$ in 1958 led to the increased adoption of periurban agriculture. Such "suburban agriculture" contributed $\sim 70 \%$ of non-staple food in Beijing, mainly consisting of vegetables and milk, to be produced by the city itself in the 1960s and 1970s (Cai, 2003). In the late 1990s, recognizing the importance of urban agriculture to sustainable urban development, Beijing's municipal government launched an official program encouraging multi-function urban agriculture in peri-urban areas by supporting the development of "agroparks", which not only produce food but also attract tourism and are used as educational tools (Cai, 2003). One of the recent experiments in urban agriculture is the Modern Agricultural Science Demonstration Park in Xiaotangshan Town, Changping District (Cai, 2003). Today, Beijing is leading the way in using smart-city technologies to make urban farming more sustainable. In addition to suburban agriculture, there are 17 golf courses with 2280 ha. greens in Beijing; some of them are located at the urban areas (Chang, 2014). The turf grass of golf course typically needs $200-400 \mathrm{~kg} \mathrm{~N} \mathrm{ha}^{-1} \mathrm{yr}^{-1}$ as $\mathrm{N}$ fertilizer to achieve high performance (Wong et al., 1998, 2002; Zhang, 2002), which should be considered as an overlooked $\mathrm{NH}_{3}$ contributor in Beijing.

\subsection{Limitations and outlook}

The data set reported in this study represents, to the best of our knowledge, the first attempt to partition urban atmospheric $\mathrm{NH}_{3}$ sources. Considering the current nascent stage of partitioning $\mathrm{NH}_{3}$ sources using stable isotope approach, there are several unsolved problems that could potentially undermine the above-mentioned results. One of our fundamental assumptions in this study is that the measured $\mathrm{NH}_{3}$ was directly from $\mathrm{NH}_{3}$ emission sources. In other words, we treated the measured $\mathrm{NH}_{3}$ as the mixture of primary $\mathrm{NH}_{3}$ sources without "gas-aerosol conversion" fractionation. But in fact, $\mathrm{NH}_{3} \leftrightarrow \mathrm{NH}_{4}^{+}$equilibrium will cause ${ }^{14} \mathrm{~N}$ to be preferentially associated with $\mathrm{NH}_{3}$ and ${ }^{15} \mathrm{~N}$ to be enriched in $\mathrm{NH}_{4}^{+}$ of PM due to the stronger associative strength of ${ }^{15} \mathrm{~N}$ than ${ }^{14} \mathrm{~N}$ in $\mathrm{NH}_{4}^{+}$(Kawashima and Kurahashi, 2011; Yeatman et al., 2001). In Beijing, earlier studies confirmed that the at- mosphere in Beijing was $\mathrm{NH}_{3}$-limited, suggesting that acidic gases could not be fully neutralized to form ammonium salts (Ianniello et al., 2010; Wang et al., 2016). Therefore, ammonium salts had much less opportunity to volatilize to $\mathrm{NH}_{3}$ to exert substantial isotopic effect through $\mathrm{NH}_{3} \leftrightarrow \mathrm{NH}_{4}^{+}$equilibrium. Still, it is critical to develop a controlled laboratory system to fundamentally understand the characteristics and mechanisms of $\mathrm{N}$ isotope fractionations during the process of $\mathrm{NH}_{3}$ transformation (Li et al., 2012).

Several additional factors could introduce uncertainty in the solutions of isotope mixing model. Given the complexity of urban $\mathrm{NH}_{3}$ sources, no definitive solution exists in a linear mixing model with one isotope system tracer $\left(\delta^{15} \mathrm{~N}\right)$ in the current study. Recommended future studies should include the combinations of different types of isotope ratio measurements and the adoption of more sophisticated Bayesian mixing models. The isotopic signature of sources like on-road traffic still remains uncertain. Some may argue that since $\mathrm{NH}_{3}$ (also $\mathrm{NO}_{x}$ ) is known to be a component of vehicle-emitted exhaust, why not collect vehicle-emitted $\mathrm{NH}_{3}$ directly from the tailpipes. To our knowledge the $\delta^{15} \mathrm{~N}$ of vehicle-emitted $\mathrm{NH}_{3}$ has not been previously assessed. The tunnel test has a unique advantage in measuring the overall isotopic signatures of vehicle-emitted pollutants. We believe that the $\delta^{15} \mathrm{~N}-\mathrm{NH}_{3}$ values of the samples collected from Handan tunnel in this study are representative as the isotopic signatures of vehicles in China.

Despite the potential limitations in this study, given the importance of $\mathrm{NH}_{3}$ to $\mathrm{PM}_{2.5}$ formation, this work can be expected to enrich the discussion on the methodologies (including stable isotope analysis) in terms of identifying the largest $\mathrm{NH}_{3}$ sources in urban atmosphere where policy efforts relating to emissions abatement can be directed to deliver the largest impact.

\section{Conclusions}

First, we establish a pool of isotopic signatures $\left(\delta^{15} \mathrm{~N}-\mathrm{NH}_{3}\right)$ for the major $\mathrm{NH}_{3}$ emission sources in China. The $\delta^{15} \mathrm{~N}-$ $\mathrm{NH}_{3}$ source inventory confirms that $\mathrm{NH}_{3}$ emitted from onroad traffic has much higher $\delta^{15} \mathrm{~N}$ values $(-14.2 \pm 2.8 \%$ ), allowing them to be differentiated from other sources, such as livestock $(-29.1 \pm 1.7 \%$ ), waste $(-37.8 \pm 3.6 \%$ ), and fertilizer $(-50.0 \pm 1.8 \%$ )

Second, we demonstrated that the isotopic source signatures of $\mathrm{NH}_{3}$ represent an emerging tool for partitioning $\mathrm{NH}_{3}$ sources. Taking advantage of the implementation of stringent air quality control measures during the APEC summit in Beijing, the IsoSource modeling results indicate that the overall contribution of traffic, waste, livestock, and fertilizer to ambient $\mathrm{NH}_{3}$ mass concentrations is $20.4,25.9,24.0$, and $29.7 \%$, respectively, in which traffic is the most sensitive to control measures. Our results clearly show that non-agricultural sources (traffic and waste) of $\mathrm{NH}_{3}$ are of critical importance 
in megacities like Beijing. Therefore, in addition to current $\mathrm{SO}_{2}$ and $\mathrm{NO}_{x}$ controls, China also needs to allocate more scientific, technical, and legal resources on controlling nonagricultural $\mathrm{NH}_{3}$ emissions in the future.

\section{Data availability}

All data in this paper are available in the Supplement.

\section{The Supplement related to this article is available online at doi:10.5194/acp-16-11635-2016-supplement.}

Acknowledgements. This work would have been impossible without the thought-provoking discussions with Yunting Fang at the Institute of Applied Ecology (IAE), Chinese Academy of Sciences. We sincerely thank Ying Tu at IAE, Yue'e Yang and $\mathrm{Zi} \mathrm{Li}$ at the Shanghai Institutes of Life Sciences, for their assistance with the isotopic analysis. We also acknowledge the Qingyue Open Environmental Data Centre (http://data.epmap.org) for the unconditional help in terms of providing criteria pollutants monitoring data. Yunhua Chang acknowledges the support of the Gao Tingyao Scholarship and the start-up grant for outstanding young scholars by NUIST. This work was partially funded by the National Natural Science Foundation of China (Grant nos. 21377029, 21277030, 40425007, and 31421092) and the State Basic Research Program (2014CB954200).

Edited by: L. Zhang

Reviewed by: two anonymous referees

\section{References}

Aneja, V. P., Schlesinger, W. H., and Erisman, J. W.: Farming pollution, Nat. Geosci., 1, 409-411, doi:10.1038/ngeo236, 2008.

Asman, W. A. and van Jaarsveld, H. A.: A variable-resolution transport model applied for $\mathrm{NH}_{x}$ in Europe, Atmos. Environ., 26, 445-464, doi:10.1016/0960-1686(92)90329-J, 1992.

Barros, C., Pinho, P., Durão, R., Augusto, S., Maìguas, C., Pereira, M. J., and Branquinho, C.: Disentangling natural and anthropogenic sources of atmospheric sulfur in an industrial region using biomonitors, Environ. Sci. Technol., 49, 2222-2229, doi:10.1021/es505292t, 2015.

Burgard, D. A., Bishop, G. A., and Stedman, D. H.: Remote sensing of ammonia and sulfur dioxide from on-road light duty vehicles, Environ. Sci. Technol., 40, 7018-7022, doi:10.1021/es061161r, 2006.

Butler, T., Marino, R., Schwede, D., Howarth, R., Sparks, J., and Sparks, K.: Atmospheric ammonia measurements at low concentration sites in the northeastern USA: Implications for total nitrogen deposition and comparison with CMAQ estimates, Biogeochemistry, 122, 191-210, doi:10.1007/s10533-014-00365, 2015.
Cai, J.: Periurban agriculture development in China: a new approach in Xiaotangshan, Beijing, Urban Agri. Mag., 9, 40-42, 2003.

Cao, J. J., Zhang, T., Chow, J. C., Watson, J. G., Wu, F., and Li, H.: Characterization of atmospheric ammonia over Xi'an, China, Aerosol Air Qual. Res., 9, 277-289, doi:10.4209/aaqr.2008.10.0043, 2009.

Cao, J. J., Chow, J. C., Tao, J., Lee, S. C., Watson, J. G., Ho, K. F., Wang, G. H., Zhu, C. S., and Han, Y. M.: Stable carbon isotopes in aerosols from Chinese cities: Influence of fossil fuels, Atmos. Environ., 45, 1359-1363, doi:10.1016/j.atmosenv.2010.10.056, 2011.

Chang, Y., Zou, Z., Deng, C., Huang, K., Collett, J. L., Lin, J., and Zhuang, G.: The importance of vehicle emissions as a source of atmospheric ammonia in the megacity of Shanghai, Atmos. Chem. Phys., 16, 3577-3594, doi:10.5194/acp-16-3577-2016, 2016.

Chang, Y. H.: Non-agricultural ammonia emissions in urban China, Atmos. Chem. Phys. Discuss., 14, 8495-8531, doi:10.5194/acpd-14-8495-2014, 2014.

Chang, Y. H., Liu, X. J, Dore, A. J., and Li, K. H.: Stemming PM 2.5 pollution in China: Re-evaluating the role of ammonia, aviation and non-exhaust road traffic emissions, Environ. Sci. Technol., 46, 13035-13036, doi:10.1021/es304806k, 2012.

Chang, Y. H., Deng, C. R., Dore, A. J., and Zhuang, G. S.: Human Excreta as a Stable and Important Source of Atmospheric Ammonia in the Megacity of Shanghai, Plos One, 10, e0144661, doi:10.1371/journal.pone.0144661, 2015.

Chen, C., Sun, Y. L., Xu, W. Q., Du, W., Zhou, L. B., Han, T. T., Wang, Q. Q., Fu, P. Q., Wang, Z. F., Gao, Z. Q., Zhang, Q., and Worsnop, D. R.: Characteristics and sources of submicron aerosols above the urban canopy $(260 \mathrm{~m})$ in Beijing, China, during the 2014 APEC summit, Atmos. Chem. Phys., 15, 1287912895, doi:10.5194/acp-15-12879-2015, 2015.

Cole, J. J., Carpenter, S. R., Kitchell, J., Pace, M. L., Solomon, C. T., and Weidel, B.: Strong evidence for terrestrial support of zooplankton in small lakes based on stable isotopes of carbon, nitrogen, and hydrogen, P. Natl. Acad. Sci., 108, 1975-1980, doi:10.1073/pnas.1012807108, 2011.

Dai, Y., Zheng, X. J., Tang, L. S., and Li, Y.: Stable oxygen isotopes reveal distinct water use patterns of two Haloxylon species in the Gurbantonggut Desert, Plant Soil, 389, 73-87, doi:10.1007/s11104-014-2342-z, 2015.

Erisman, J. W., Sutton, M. A., Galloway, J., Klimont, Z., and Winiwarter, W.: How a century of ammonia synthesis changed the world, Nat. Geosci., 1, 636-639, doi:10.1038/ngeo325, 2008.

Felix, J. D., Elliott, E. M., and Shaw, S. L.: Nitrogen isotopic composition of coal-fired power plant $\mathrm{NO}_{x}$ : influence of emission controls and implications for global emission inventories, Environ. Sci. Technol., 46, 3528-3535, doi:10.1021/es203355v, 2012.

Felix, J. D., Elliott, E. M., Gish, T. J., McConnell, L. L., and Shaw, S. L.: Characterizing the isotopic composition of atmospheric ammonia emission sources using passive samplers and a combined oxidation-bacterial denitrifier approach, Rapid Commun. Mass Sp., 27, 2239-2246, doi:10.1002/rcm.6679, 2013.

Felix, J. D., Elliott, E. M., Gish, T. J., Maghirang, R., Cambal, L., and Clougherty, J.: Examining the transport of ammonia emissions across landscapes using nitrogen isotope ratios, Atmos. Environ., 95, 563-570, doi:10.1016/j.atmosenv.2014.06.061, 2014. 
Flechard, C. R., Massad, R.-S., Loubet, B., Personne, E., Simpson, D., Bash, J. O., Cooter, E. J., Nemitz, E., and Sutton, M. A.: Advances in understanding, models and parameterizations of biosphere-atmosphere ammonia exchange, Biogeosciences, 10, 5183-5225, doi:10.5194/bg-10-5183-2013, 2013.

Fowler, D., Pilegaard, K., Sutton, M. A., Ambus, P., Raivonen, M., Duyzer, J., Simpson, D., Fagerli, H., Fuzzi, S., and Schjørring, J. K.: Atmospheric composition change: Ecosystemsatmosphere interactions, Atmos. Environ., 43, 5193-5267, doi:10.1016/j.atmosenv.2009.07.068, 2009.

Fu, X., Wang, S., Zhao, B., Xing, J., Cheng, Z., Liu, H., and Hao, J.: Emission inventory of primary pollutants and chemical speciation in 2010 for the Yangtze River Delta region, China, Atmos. Environ., 70, 39-50, doi:10.1016/j.atmosenv.2012.12.034, 2013.

Galloway, J. N., Aber, J. D., Erisman, J. W., Seitzinger, S. P., Howarth, R. W., Cowling, E. B., and Cosby, B. J.: The nitrogen cascade, Biosci., 53, 341-356, doi:10.1641/00063568(2003)053[0341:TNC]2.0.CO;2, 2003.

Giesemann, A., Jäger, H. J., Norman, A., Krouse, H., and Brand, W.: Online sulfur-isotope determination using an elemental analyzer coupled to a mass spectrometer, Anal. Chem., 66, 2816-2819, doi:10.1021/ac00090a005, 1994.

Habicht, K. S. and Canfield, D. E.: Sulfur isotope fractionation during bacterial sulfate reduction in organic-rich sediments, Geochim. Cosmochim. Ac., 61, 5351-5361, doi:10.1016/S00167037(97)00311-6, 1997.

Huang, C., Chen, C. H., Li, L., Cheng, Z., Wang, H. L., Huang, H. Y., Streets, D. G., Wang, Y. J., Zhang, G. F., and Chen, Y. R.: Emission inventory of anthropogenic air pollutants and VOC species in the Yangtze River Delta region, China, Atmos. Chem. Phys., 11, 4105-4120, doi:10.5194/acp-11-4105-2011, 2011.

Huang, X., Song, Y., Li, M., Li, J., Huo, Q., Cai, X., Zhu, T., Hu, M., and Zhang, H.: A high-resolution ammonia emission inventory in China, Global Biogeochem. Cy., 26, GB1030, doi:10.1029/2011GB004161, 2012.

Ianniello, A., Spataro, F., Esposito, G., Allegrini, I., Rantica, E., Ancora, M. P., Hu, M., and Zhu, T.: Occurrence of gas phase ammonia in the area of Beijing (China), Atmos. Chem. Phys., 10, 9487-9503, doi:10.5194/acp-10-9487-2010, 2010.

Jautzy, J. J., Ahad, J. M., Gobeil, C., Smirnoff, A., Barst, B. D., and Savard, M. M.: Isotopic evidence for oil sands petroleum coke in the Peace-Athabasca Delta, Environ. Sci. Technol., 49, 1206212070, doi:10.1021/acs.est.5b03232, 2015.

Ju, X. T., Xing, G. X., Chen, X. P., Zhang, S. L., Zhang, L. J., Liu, X. J., Cui, Z. L., Yin, B., Christie, P., Zhu, Z. L., and Zhang, F. S.: Reducing environmental risk by improving $\mathrm{N}$ management in intensive Chinese agricultural systems, P. Natl. Acad. Sci., 106, 3041-3046, doi:10.1073/pnas.0813417106, 2009.

Kang, Y., Liu, M., Song, Y., Huang, X., Yao, H., Cai, X., Zhang, H., Kang, L., Liu, X., Yan, X., He, H., Zhang, Q., Shao, M., and Zhu, T.: High-resolution ammonia emissions inventories in China from 1980 to 2012, Atmos. Chem. Phys., 16, 2043-2058, doi:10.5194/acp-16-2043-2016, 2016.

Kawashima, H. and Kurahashi, T.: Inorganic ion and nitrogen isotopic compositions of atmospheric aerosols at Yurihonjo, Japan: Implications for nitrogen sources, Atmos. Environ., 45, 63096316, doi:10.1016/j.atmosenv.2011.08.057, 2011.

Kean, A. J., Littlejohn, D., Ban-Weiss, G. A., Harley, R. A., Kirchstetter, T. W., and Lunden, M. M.: Trends in on-road vehi- cle emissions of ammonia, Atmos. Envion., 43, 1565-1570, doi:10.1016/j.atmosenv.2008.09.085, 2009.

Lee, C., Hristov, A. N., Cassidy, T., and Heyler, K.: Nitrogen isotope fractionation and origin of ammonia nitrogen volatilized from cattle manure in simulated storage, Atmosphere, 2, 256270, doi:10.3390/atmos2030256, 2011.

Li, J., Xie, S. D., Zeng, L. M., Li, L. Y., Li, Y. Q., and Wu, R. R.: Characterization of ambient volatile organic compounds and their sources in Beijing, before, during, and after Asia-Pacific Economic Cooperation China 2014, Atmos. Chem. Phys., 15, 7945-7959, doi:10.5194/acp-15-7945-2015, 2015.

Li, L., Lollar, B. S., Li, H., Wortmann, U. G., and LacrampeCouloume, G.: Ammonium stability and nitrogen isotope fractionations for $\mathrm{NH}_{4}^{+}-\mathrm{NH}_{3(\text { aq) }}-\mathrm{NH}_{3 \text { (gas) }}$ systems at $20-70^{\circ} \mathrm{C}$ and $\mathrm{pH}$ of 2-13: Applications to habitability and nitrogen cycling in low-temperature hydrothermal systems, Geochim. Cosmochim. Ac., 84, 280-296, doi:10.1016/j.gca.2012.01.040, 2012.

Li, M., Zhang, Q., Kurokawa, J., Woo, J.-H., He, K. B., Lu, Z., Ohara, T., Song, Y., Streets, D. G., Carmichael, G. R., Cheng, Y. F., Hong, C. P., Huo, H., Jiang, X. J., Kang, S. C., Liu, F., Su, H., and Zheng, B.: MIX: a mosaic Asian anthropogenic emission inventory for the MICS-Asia and the HTAP projects, Atmos. Chem. Phys. Discuss., 15, 34813-34869, doi:10.5194/acpd-1534813-2015, 2015.

Liu, D., Fang, Y., Tu, Y., and Pan, Y.: Chemical method for nitrogen isotopic analysis of ammonium at natural abundance, Anal. Chem., 86, 3787-3792, doi:10.1021/ac403756u, 2014.

Liu, J., Li, J., Zhang, Y., Liu, D., Ding, P., Shen, C., Shen, K., He, Q., Ding, X., Wang, X., Chen, D., Szidat, S., and Zhang, G.: Source apportionment using radiocarbon and organic tracers for $\mathrm{PM}_{2.5}$ carbonaceous aerosols in Guangzhou, South China: Contrasting local- and regional-scale haze events, Environ. Sci. Technol., 48, 12002-12011, doi:10.1021/es503102w, 2014.

Liu, T., Wang, X., Wang, B., Ding, X., Deng, W., Lü, S., and Zhang, Y.: Emission factor of ammonia $\left(\mathrm{NH}_{3}\right)$ from on-road vehicles in China: Tunnel tests in urban Guangzhou, Environ. Res. Lett., 9, 064027, doi:10.1088/1748-9326/9/6/064027, 2014.

Liu, X. Y., Xiao, H. Y., Liu, C. Q., Li, Y. Y., and Xiao, H. W.: Atmospheric transport of urban-derived $\mathrm{NH}_{x}$ : Evidence from nitrogen concentration and $\delta^{15} \mathrm{~N}$ in epilithic mosses at Guiyang, SW China, Environ. Pollut., 156, 715-722, doi:10.1016/j.envpol.2008.06.011, 2008.

Meng, Z. Y., Lin, W. L., Jiang, X. M., Yan, P., Wang, Y., Zhang, Y. M., Jia, X. F., and Yu, X. L.: Characteristics of atmospheric ammonia over Beijing, China, Atmos. Chem. Phys., 11, 61396151, doi:10.5194/acp-11-6139-2011, 2011.

Michalski, G., Bhattacharya, S. K., and Girsch, G.: $\mathrm{NO}_{x}$ cycle and the tropospheric ozone isotope anomaly: an experimental investigation, Atmos. Chem. Phys., 14, 4935-4953, doi:10.5194/acp14-4935-2014, 2014.

Perrino, C., Catrambone, M., Di Bucchianico, A. D. M., and Allegrini, I.: Gaseous ammonia in the urban area of Rome, Italy and its relationship with traffic emissions, Atmos. Environ., 36, 5385-5394, doi:10.1016/S1352-2310(02)00469-7, 2002.

Phillips, D. L. and Gregg, J. W.: Source partitioning using stable isotopes: Coping with too many sources, Oecologia, 136, 261269, doi:10.1007/s00442-003-1218-3, 2003.

Puchalski, M. A., Sather, M. E., Walker, J. T., Lehmann, C. M., Gay, D. A., Mathew, J., and Robarge, W. P.: Passive am- 
monia monitoring in the United States: Comparing three different sampling devices, J. Environ. Monit., 13, 3156-3167, doi:10.1039/C1EM10553A, 2011.

Rudolph, J., Lowe, D. C., Martin, R., and Clarkson, T.: A novel method for compound specific determination of $\delta^{13} \mathrm{C}$ in volatile organic compounds at ppt levels in ambient air, Geophys. Res. Lett., 24, 659-662, doi:10.1029/97GL00537, 1997.

Schlesinger, W. H. and Hartley, A. E.: A global budget for atmospheric $\mathrm{NH}_{3}$, Biogeochemistry, 15, 191-211, doi:10.1007/BF00002936, 1992.

Singh, S. and Kulshrestha, U. C.: Rural versus urban gaseous inorganic reactive nitrogen in the Indo-Gangetic plains (IGP) of India, Environ. Res. Lett., 9, 125004, doi:10.1088/17489326/9/12/125004, 2014.

Skinner, R., Ineson, P., Jones, H., Sleep, D., and Theobald, M.: Sampling systems for isotope-ratio mass spectrometry of atmospheric ammonia, Rapid Commun. Mass Sp., 20, 81-88, doi:10.1002/rcm.2279, 2006.

Sutton, M. A., Dragosits, U., Y. Tang, and Fowler, D.: Ammonia emissions from non-agricultural sources in the UK, Atmos. Environ., 34, 855-869, doi:10.1016/S1352-2310(99)00362-3, 2000.

Sutton, M. A., Oenema, O., Erisman, J. W., Leip, A., van Grinsven, H., and Winiwarter, W.: Too much of a good thing, Nature, 472, 159-161, doi:10.1038/472159a, 2011.

Tang, G., Zhu, X., Hu, B., Xin, J., Wang, L., Münkel, C., Mao, G., and Wang, Y.: Impact of emission controls on air quality in Beijing during APEC 2014: lidar ceilometer observations, Atmos. Chem. Phys., 15, 12667-12680, doi:10.5194/acp15-12667-2015, 2015.

Tang, Y., Cape, J., and Sutton, M. A.: Development and types of passive samplers for monitoring atmospheric $\mathrm{NO}_{2}$ and $\mathrm{NH}_{3}$ concentrations, Sci. World J., 1, 513-529, doi:10.1100/tsw.2001.82, 2001.

Walters, W. W. and Michalski, G.: Theoretical calculation of nitrogen isotope equilibrium exchange fractionation factors for various $\mathrm{NO}_{y}$ molecules, Geochim. Cosmochim. Ac., 164, 284-297, doi:10.1016/j.gca.2015.05.029, 2015.

Walters, W. W., Tharp, B. D., Fang, H., Kozak, B. J., and Michalski, G.: Nitrogen isotope composition of thermally produced $\mathrm{NO}_{x}$ from various fossil-fuel combustion sources, Environ. Sci. Technol., 49, 11363-11371, doi:10.1021/acs.est.5b02769, 2015.

Walters, W. W., Simonini, D. S., and Michalski, G.: Nitrogen isotope exchange between $\mathrm{NO}$ and $\mathrm{NO}_{2}$ and its implications for $\delta^{15} \mathrm{~N}$ variations in tropospheric $\mathrm{NO}_{x}$ and atmospheric nitrate, Geophys. Res. Lett., 43, 440-448, doi:10.1002/2015GL066438, 2016.

Wang, S. X., Xing, J., Jang, C. R., Zhu, Y., Fu, J. S., and Hao, J. M.: Impact assessment of ammonia emissions on inorganic aerosols in East China using response surface modeling technique, Environ. Sci. Technol., 45, 9293-9300, doi:10.1021/es2022347, 2011.

Wang, Y., Zhang, Q. Q., He, K., Zhang, Q., and Chai, L.: Sulfatenitrate-ammonium aerosols over China: response to 2000-2015 emission changes of sulfur dioxide, nitrogen oxides, and ammonia, Atmos. Chem. Phys., 13, 2635-2652, doi:10.5194/acp-132635-2013, 2013.

Wang, Y.-L., Liu, X.-Y., Song, W., Yang, W., Han, B., Dou, X.Y., Zhao, X.-D., Song, Z.-L., Liu, C.-Q., and Bai, Z.-P.: Isotopic partitioning of nitrogen in $\mathrm{PM}_{2.5}$ at Beijing and a background site of China, Atmos. Chem. Phys. Discuss., doi:10.5194/acp-2016187, in review, 2016.

Warneck, P.: Chemistry of the Natural Atmosphere, Academic Press, San Diego, Calif., USA, 426-441, 1999.

Wong, J., Chan, C., and Cheung, K.: Nitrogen and phosphorus leaching from fertilizer applied on golf course: Lysimeter study, Water Air Soil Pollut., 107, 335-345, doi:10.1023/A:1005096122921, 1998.

Wong, J. W. C., Chan, C. W. Y., and Cheung, K. C.: Research progress about the impact of fertilizer and pesticide on the environment of golf course, Grassland and Turf, 4, 6-10, 2002 (in Chinese with English abstract).

Xiao, H. W., Xiao, H. Y., Long, A. M., and Wang, Y. L.: Who controls the monthly variations of $\mathrm{NH}_{4}^{+}$nitrogen isotope composition in precipitation?, Atmos. Environ., 54, 201-206, doi:10.1016/j.atmosenv.2012.02.035, 2012.

Xiao, H. W., Xie, L. H., Long, A. M., Ye, F., Pan, Y. P., Li, D. N., Long, Z. H., Chen, L., Xiao, H. Y., and Liu, C. Q.: Use of isotopic compositions of nitrate in TSP to identify sources and chemistry in South China Sea, Atmos. Environ., 109, 70-78, doi:10.1016/j.atmosenv.2015.03.006, 2015.

Xiao, H. Y. and Liu, C. Q.: Sources of nitrogen and sulfur in wet deposition at Guiyang, southwest China, Atmos. Environ., 36, 5121-5130, doi:10.1016/S1352-2310(02)00649-0, 2002.

Xu, W., Luo, X. S., Pan, Y. P., Zhang, L., Tang, A. H., Shen, J. L., Zhang, Y., Li, K. H., Wu, Q. H., Yang, D. W., Zhang, Y. Y., Xue, J., Li, W. Q., Li, Q. Q., Tang, L., Lu, S. H., Liang, T., Tong, Y. A., Liu, P., Zhang, Q., Xiong, Z. Q., Shi, X. J., Wu, L. H., Shi, W. Q., Tian, K., Zhong, X. H., Shi, K., Tang, Q. Y., Zhang, L. J., Huang, J. L., He, C. E., Kuang, F. H., Zhu, B., Liu, H., Jin, X., Xin, Y. J., Shi, X. K., Du, E. Z., Dore, A. J., Tang, S., Collett Jr., J. L., Goulding, K., Sun, Y. X., Ren, J., Zhang, F. S., and Liu, X. J.: Quantifying atmospheric nitrogen deposition through a nationwide monitoring network across China, Atmos. Chem. Phys., 15, 12345-12360, doi:10.5194/acp-15-12345-2015, 2015a.

Xu, W. Q., Sun, Y. L., Chen, C., Du, W., Han, T. T., Wang, Q. Q., Fu, P. Q., Wang, Z. F., Zhao, X. J., Zhou, L. B., Ji, D. S., Wang, P. C., and Worsnop, D. R.: Aerosol composition, oxidation properties, and sources in Beijing: results from the 2014 Asia-Pacific Economic Cooperation summit study, Atmos. Chem. Phys., 15, 13681-13698, doi:10.5194/acp-15-13681-2015, 2015 b.

Ye, X. N., Ma, Z., Zhang, J., Du, H., Chen, J., Chen, H., Chen, H., Yang, X., Gao, W., and Geng, F.: Important role of ammonia on haze formation in Shanghai, Environ. Res. Lett., 6, 024019 , doi:10.1088/1748-9326/6/2/024019, 2011.

Yeatman, S., Spokes, L., Dennis, P., and Jickells, T.: Comparisons of aerosol nitrogen isotopic composition at two polluted coastal sites, Atmos. Environ., 35, 1307-1320, doi:10.1016/S13522310(00)00408-8, 2001.

Zbieranowski, A. L. and Aherne, J.: Ambient concentrations of atmospheric ammonia, nitrogen dioxide and nitric acid across a rural-urban-agricultural transect in southern Ontario, Canada, Atmos. Environ., 62, 481-491, doi:10.1016/j.atmosenv.2012.08.040, 2012.

Zhang, Q., Streets, D. G., Carmichael, G. R., He, K. B., Huo, H., Kannari, A., Klimont, Z., Park, I. S., Reddy, S., Fu, J. S., Chen, D., Duan, L., Lei, Y., Wang, L. T., and Yao, Z. L.: Asian emissions in 2006 for the NASA INTEX-B mission, Atmos. Chem. Phys., 9, 5131-5153, doi:10.5194/acp-9-5131-2009, 2009. 
Zhang, R. L.: Research advances on fertilizers application to lawn, Trop. Agric. Sci., 22, 77-81, 2002 (in Chinese with English abstract).

Zhang, Y., Dore, A. J., Ma, L., Liu, X. J., Ma, W. Q., Cape, J. N., and Zhang, F. S.: Agricultural ammonia emissions inventory and spatial distribution in the North China Plain, Environ. Pollut., 158, 490-501, doi:10.1016/j.envpol.2009.08.033, 2010.
Zhelezinskaia, I., Kaufman, A. J., Farquhar, J., and Cliff, J.: Large sulfur isotope fractionations associated with Neoarchean microbial sulfate reduction, Science, 346, 742-744, doi:10.1126/science.1256211, 2014. 